\title{
Plague, Pentecostalism, and Pastoral Guidance
}

\section{Luther's Wisdom for the Contemporary Church}

\author{
Geoffrey Butler | ORCID: 0000-0001-6824-3699 \\ Wycliffe College, Toronto, Ontario, Canada \\ geoffrey.butler@mail.utoronto.ca
}

\begin{abstract}
Plagues and pandemics are nothing new for the Christian church. Throughout its history, believers have been forced to grapple with outbreaks, the latest being the COVID-19 crisis of 2020. As a relatively young branch of the Christian faith, Pentecostalism itself does not have a great deal of experience with this subject compared to many older traditions. In addition, with its emphasis on divine healing, a triumphalist attitude has unfortunately hindered some segments of the movement from developing a robust response to sickness and suffering at all. Martin Luther's sixteenth-century response to the Black Death outbreak in Germany, however, might offer a prime example for contemporary Pentecostals to emulate. His pastoral wisdom, approach to suffering, and distinctive theology of the cross together compose a prudent yet ultimately optimistic take on how Christians should behave in such instances, making his voice an invaluable one for the contemporary church to learn from.
\end{abstract}

\section{Keywords}

Luther - pandemic - Pentecostalism - cross - plague

The COVID-19 outbreak has hardly been the first occasion on which Christians have grappled with a pandemic. Just one hundred fifty years after the resurrection of Christ, the Antonine plague decimated the Roman Empire, killing somewhere between a quarter and a third of its population. ${ }^{1}$ Throughout his-

1 Rodney Stark, The Triumph of Christianity: How the Jesus Movement Became the World's Largest 
tory, such theological giants as St. Cyprian, Julian of Norwich, John Calvin, and Charles Spurgeon have found themselves in the midst of outbreaks that threatened the lives of their contemporaries. ${ }^{2}$ Martin Luther was no exception; when the Black Death swept through Germany in the summer of 1527 , he penned a letter to his ministerial colleague Johann Hess of Breslau, responding to his inquiry concerning "whether it is proper for a Christian to run away from a deadly plague." ${ }^{3}$ As William Russell notes, Luther's letter "combines theological insight with practical care," highlighting how his experience of providing "pastoral and practical care of the sick" during the outbreak in Wittenberg gave rise to his perspective on how Christians should respond to such scenarios. ${ }^{4}$

Pentecostalism, a relatively young branch of Christianity, has not had as much time as some other traditions to reflect on how believers should respond to disease outbreaks. Moreover, the ability of some segments of the movement to do so may be unwittingly hampered by aspects of its own theology. As David Courey details in What Has Wittenberg to Do with Azusa?, the pentecostal tradition has long exhibited certain triumphalist tendencies, due in no small part to its emphasis on divine healing. ${ }^{5}$ Douglas John Hall, from whom Courey borrows his definition of "triumphalism," defines it as when groups

present themselves as full and complete accounts of reality, leaving litthe if any room for debate or difference of opinion and expecting of their adherents unflinching belief and loyalty. Such a tendency is triumphalistic in the sense that it triumphs - at least in its own self-estimate-over all ignorance, uncertainty, doubt, and incompleteness, as well, of course, as every other point of view. ${ }^{6}$

Religion (New York: HarperOne, 2011), 114. Stark argues that the compassionate response of the early Christian church to such crises served as a catalyst for the spread of the gospel across a deeply pagan culture.

2 For a brief, introductory overview of the history of pandemics within the church, see John D. Witvliet et al., "Pandemics and Public Worship Throughout History," March 23, 2020, https://worship.calvin.edu/resources/resource-library/pandemics-and-public-worship -throughout-history.

3 Martin Luther, "Whether One May Flee from a Deadly Plague," in Martin Luther's Basic Theological Writings, ed. William R. Russell (Minneapolis: Fortress Press, 2012), 475.

4 William R. Russell, editor's preface to Luther's "Whether One May Flee from a Deadly Plague," in Martin Luther's Basic Theological Writings, ed. William R. Russell (Minneapolis: Fortress Press, 2012), 475.

5 David J. Courey, What Has Wittenberg to Do with Azusa?: Luther's Theology of the Cross and Pentecostal Triumphalism, T \& T Clark Theology (London: T \& T Clark, 2016).

6 Douglas John Hall, The Cross in Our Context: Jesus and the Suffering World (Minneapolis: Fortress Press, 2003), 15 . 
Many Pentecostals would reject this characterization, noting that debates and differences abound within the movement. ${ }^{7}$ His depiction of "unflinching belief and loyalty," while characteristic of some ministerial contexts, hardly represents the average classical pentecostal congregation. ${ }^{8}$ Amos Yong, for example, notes that physicians were among the first generation of pentecostal believers; ${ }^{9}$ medical science and divine healing, therefore, have never been considered mutually exclusive by the entire movement. He also points to a late twentieth-century British survey in which nearly 94 percent of pentecostal ministers affirmed modern medicine as a divine blessing as evidence that the movement continues to value the discipline. ${ }^{10}$ Likewise, a 2010 volume entitled Science and the Spirit, coedited by Yong and James K.A. Smith, explores various pentecostal approaches to technology, physics, evolutionary biology, and other fields pertinent to medical science, ${ }^{11}$ further indicating that pentecostal thought - whether historic or contemporary-on this topic is far from monolithic. Nevertheless, there are reasons to believe that triumphalist attitudes, as defined by Hall, have also been widespread in the movement from the beginning. Highlighting the perspective of the leaders of the Azusa Street revival, particularly that of former Holiness preacher William Seymour, Courey observes that, for many Pentecostals,

Just as the sin issue was dealt with at the cross, not just the penalty but the power and presence of sin, so the matter of sickness could be entirely dispensed with. The sound of such pronouncements reverberates through all of Pentecostalism in its various permutations, and raises questions that must be addressed ... Healing on this view was Christological, obtained

Indeed, entire monographs have been written outlining the diversity of pentecostalcharismatic thought on this around the world. See, for example, Candy Gunther Brown, ed., Global Pentecostal and Charismatic Healing (Oxford: Oxford University Press, 2011).

For instance, the Assemblies of God declares in its position paper on divine healing that it "neither opposes nor competes with medical doctors." Moreover, it recognizes "that until Jesus comes we groan because we have not yet received the full redemption of our bodies." See Divine Healing, Adopted by the General Presbytery in Session August 9-11, 2010, https://ag.org/Beliefs/Position-Papers/divine-healing. https://ag.org/Beliefs/Position-Pap ers/divine-healing.

9 Amos Yong, The Spirit of Creation: Modern Science and Divine Action in the PentecostalCharismatic Imagination, Pentecostal Manifestos (Grand Rapids, MI: Eerdmans, 2011), 6.

10 Yong, The Spirit of Creation, 6. For a contemporary theology of disability that might also inform how Pentecostals understand healing, see also Amos Yong, The Bible, Disability, and the Church: A New Vision of the People of God (Grand Rapids, MI: Eerdmans, 2011).

11 See also James K.A. Smith and Amos Yong. Science and the Spirit: A Pentecostal Engagement with the Sciences (Bloomington: Indiana University Press, 2010). 
once and for all "by his stripes" and imparted by Christ's life in the believer through the Holy Spirit. It was a promise to be claimed. ${ }^{12}$

Again, this is not to say that the movement lacks resources to respond to pandemics. Less than two decades after the Azusa Street revival, Pentecostalism faced the Spanish influenza outbreak, often with great wisdom. Kim Alexander documents that while Pentecostals trusted the "Great Physician" to heal sickness, many postponed services and conferences, complying with lockdown orders in a commendable display of prudence. ${ }^{13}$ Yet, it is not difficult to see how the triumphalist assumptions Courey highlights would make dealing with the harsh reality of a pandemic problematic, even impossible, when taken to its most extreme expressions, as some segments of the movement have done. ${ }^{14}$

Given this sympathy toward triumphalism, coupled with the tendency to focus on immediate release from bodily illness, developing a mature pentecostal theology of suffering might require further engagement with the historic Christian tradition. This article will argue that Luther's response to the Black Death serves as an excellent model for Pentecostalism as it responds to current and future disease outbreaks, noting how his practical sensibilities position him to inform this ongoing conversation within the movement. Moreover, the way in which Luther views God's revelation of himself in the cross as foundational may help Pentecostals consider afresh how Christians should think about suffering and sickness. To be clear, the problem is not a strong affirmation of divine healing per se; Pentecostals have long cherished this distinctive on firm biblical grounds. ${ }^{15}$ The argument is not that Pentecostals should aban-

12 Courey, What Has Wittenberg to Do with Azusa?, 246. Consequently, Synan observes that "In the early years of the movement, Pentecostals felt it was a sin to take medicine or even visit a doctor," an assumption founded on their doctrine of healing. See Vinson Synan, The Holiness-Pentecostal Tradition: Charismatic Movements in the Twentieth Century, and ed. (Grand Rapids, MI: Eerdmans, 1997), 192.

13 Kimberly Ervin Alexander, Pentecostal Healing: Models in Theology and Practice, Journal of Pentecostal Theology Supplement Series 29 (Blandford Forum: Deo, 20o6), 216-217.

14 For reference, one might observe the outlandish expressions of some charismatic televangelists; Kenneth Copeland, near the beginning of the covid-19 outbreak, openly encouraged his congregants to "forget about corona," furthering elaborating, "I want you in my church. If we have to pass out thermometers. If we find one with a fever, let's get him healed right there" (see Leonardo Blair, "Kenneth Copeland Calls Coronavirus 'Very Weak Strain of Flu,' Says Healthy People Shouldn't Fear," March 13, 2020, https://www .christianpost.com/news/kenneth-copeland-calls-coronavirus-very-weak-strain-of-flu -healthy-people-shouldnt-fear.html).

For an example of a pentecostal statement on this, see Pentecostal Assemblies of Canada. 
don their position, but rather that they should strive for greater balance. The fact that talk of how to deal properly with a pandemic has become unavoidable in today's world makes such a conversation seem timely.

There are numerous reasons why Pentecostals should look to Luther as a prime dialogue partner in grappling with suffering and disease. One is the absence of modernistic assumptions in his approach, unlike those of many of early Pentecostalism's contemporaries. ${ }^{16}$ It has been suggested that Pentecostalism is, in some ways, an anti-modern ${ }^{17}$ or even postmodern movement; it is skeptical of rationalism, for instance, and places a high premium upon community and experience. ${ }^{18}$ Thus, a premodern figure like Luther, unbeholden to modernism's influence in his doctrines of healing, medicine, or providence, would be better suited as a conversation partner than those dependent upon it. ${ }^{19}$ This becomes apparent when considering the question of theodicy; as Ephraim Radner notes, this very idea is a modern one, which "arises in early modernity, not because suffering is new, but because it can no longer be endured according

Statement of Fundamental \& Essential Truths: Adopted by General Conference, 2014 (Mississauga, ON: Pentecostal Assemblies of Canada, 2014), 3.

16 For a discussion of the fundamental differences between fundamentalism, modernism, and Pentecostalism, see James Robinson, Divine Healing: The Years of Expansion, 19o61930: Theological Variation in the Transatlantic World (Eugene, OR: Pickwick Publications, 2014), particularly chapter 5, "The Developing Healing Scene in North America." Robinson observes that pentecostal leaders such as Aimee Semple McPherson were averse to modernistic thought, with its higher criticism of the Bible and assumption of evolutionary biology (204).

17 Adam Stewart, "Pentecostalism in the Modern World," Axis Mundi 9 (2008): 1-24, https:// doi.org/10.29173/axismundi76.

18 See, for example, Bradley Truman Noel, Pentecostalism, Secularism, and Post Christendom (Eugene, OR: Wipf \& Stock, 2015), 69.

19 The response offered by early Pentecostalism's contemporaries during the Spanish flu, for example, leaves much to be desired in looking for a theological conversation partner. Howard Philips remarks that despite the modernist's attempt to reconcile modern medical science and faith in his South African context, many Christians became "dissatisfied with mainstream Christianity's inability to protect them or to provide an adequate explanation of the disaster," and therefore "abandoned their mission churches in the wake of the epidemic and established breakaway churches of their own." See Howard Phillips, "Why Did It Happen? Religious Explanations of the Spanish Flu Epidemic in South Africa." Historically Speaking 9, no. 7 (September-October 2008), 35 . 
to the previously expected claims of divine order or sovereignty."20 Thus, perhaps instead of assuming the modern approach and looking for an answer as to why evil occurs, Pentecostals might consider how those of Luther's era considered the problem before the emergence of modernism and, consequently, of theodicy.

An even more fundamental (though intrinsically related) reason for choosing Luther as a dialogue partner concerns his distinctive theological method. To understand how Luther was able to competently respond to the plague, it is imperative to grasp that, for him, theology must be grounded not in abstract speculation about God's nature, but the revelation of himself in the crucified Christ. "The theology of the cross," Loewenich charges, "is a principle of Luther's entire theology and it may not be confined to a special period in his theological development."21 It is this method that Courey pinpoints as a corrective to pentecostal triumphalism. ${ }^{22}$ Luther held that a genuine theologian must be formed through experiencing hardship; ${ }^{23}$ after all, through the incarnation and crucifixion of Christ, the way in which God revealed himself was not in glory and majesty, but in humility and suffering. ${ }^{24}$ Consequently, Luther rebuked "theologians of glory" who looked for God's revelation in manifestations of power, claiming that any individual who does so "does not deserve to be called a theologian." 25 In light of the cross, one must look for God in weakness; "God is to be found," Luther insists, "precisely where the theologians of glory are horrified to find: as a kid in a crib, as a criminal on a cross, as a corpse in a crypt."26

The implications of this method are obvious; if God has revealed himself via suffering, and all of theology must be approached from this vantage point, then everyday life - its challenges, confrontations, and misfortunes-must be viewed through this lens too. As Robert Kolb details:

$20 \quad$ Ephraim Radner, A Profound Ignorance: Modern Pneumatology and Its Anti-Modern Redemption (Waco, TX: Baylor University Press, 2019), 102.

21 Walther von Loewenich, Luther's Theology of the Cross, trans. Herbert J. A Bouman (Minneapolis: Augsburg, 1976), 13 .

22 See Courey, What Has Wittenberg to Do with Azusa?

23 Alister McGrath, foreword to Dennis Ngien, Luther's Theology of the Cross: Christ in Luther's Sermons on John (Eugene, OR: Cascade Books, 2018), ix.

24 Ngien, Luther's Theology of the Cross, 4-5. Concurring with Loewenich, Ngien elsewhere explains, "The cross, for Luther, is the context for doing theology; it is so central that everything is challenged and tested by it" (xi).

25 Martin Luther, Luther's Works, ed. Jaroslav Pelikan and H.T. Lehman (St. Louis, MO: Concordia, 1955-1967), 31.52.

26 Luther, Luther's Works, 31.53. 
Luther did not believe that God's mercy and goodness reveal themselves only in the cross, but the cross illuminates the more ambiguous encounters with the Creator's providential goodness in the course of his supplying the needs of daily life ... This theologia crucis came to function as Luther's alternative to what Gottfried Wilhelm Leibniz later labeled "theodicy," the human defense of God in view of the mystery of how evil can exist when God is both good and almighty. ${ }^{27}$

Few Christians, during upheaval, can resist the temptation to desire such a theodicy. If God truly is all-good and all-powerful, we ask ourselves, why do such tragedies come to pass? Some argue that God has limited himself in such a way that humans may override his will, thereby bringing disaster upon themselves and others; some appeal to mystery; others contend that all suffering serves an ultimate purpose under God's providence. At times, Luther himself indicates that plagues may be instances of God's judgment, part of his "decree ... to which we must patiently submit," ${ }^{28}$ comparable to some Pentecostals such as G.F. Taylor, who pondered whether the Spanish flu outbreak of their time might be an occasion of divine chastisement. ${ }^{29}$ However, the Reformer does not adopt any one approach to explain the problem of evil as such. As Kolb continues:

Luther believed that the final answers to questions regarding evil in human life cannot be resolved if both God's goodness and his power are maintained, in accord with Scripture's presentation of who God is. Therefore, his theology of the cross asserted that human beings can do no more than cling to God in trust when evil comes from inside or outside, when they are victims of evil and when they perpetrate evil. ${ }^{30}$

Unlike modern believers, Luther does not so much attempt to resolve the question of why evil exists as resolve to cling to the cross and its revelation of God, despite whatever evil might come his way. His admission that fully resolving the problem of evil was impossible did not lead to his rejection of the faith nor to a fatalistic attitude toward life. ${ }^{31} \mathrm{He}$ forthrightly acknowledges the presence of

27 Robert Kolb, Martin Luther: Confessor of the Faith, Christian Theology in Context (Oxford: Oxford University Press, 2009), 56.

28 Luther, "Whether One May Flee," 480.

29 Alexander, Pentecostal Healing, 217.

$30 \quad$ Kolb, Martin Luther, 68.

31 Robert Kolb, Foreword in Dennis Ngien, Fruit for the Soul: Luther on the Lament Psalms (Minneapolis, MN: Augsburg Fortress, 2015), xiii. 
evil in the world, but finds his hope in the cross. Here, God has revealed himself in suffering; therefore, we not only know that he sympathizes with our pain but also that he reveals himself amid it. Thus, Dennis Ngien explains, "Luther's theology allows a discourse with God in which praise and lamentation find their rightful place." 32 Though he did not offer a modern theodicy, Luther did address the deeper pastoral need, ${ }^{33}$ one that is only exacerbated during a pandemic.

While many are familiar with the first wave of the bubonic plague that rocked Europe in the mid fourteenth century, fewer might be aware of the subsequent outbreaks that disrupted life into Luther's era. One caused the university in Wittenberg to close in August 1527, forcing the students home while Luther stayed to care for the sick. ${ }^{34}$ His letter to Hess and "his fellow-servants"35 of the gospel combines Luther's assessment of how Christians should think about plagues in general and advice for the situation at hand. Breslau and Wittenberg were hit hard enough to convince many to evacuate; however, the wisdom (or morality) of doing so remained unresolved. With Luther's characteristic bluntness on full display, several principles appear especially noteworthy.

\subsection{A Matter of Conscience}

First, Luther carefully nuances whether Christians should flee by recognizing that a certain individual's conscience may vary regarding when, or if, to do so. This is not an inherently righteous or unrighteous characteristic; Luther acknowledges that some with "strong faith" might be comfortable remaining during an outbreak, while others with "weak" faith may flee. "I cannot censure the former for their excellent decision" Luther says. "They uphold a good cause, namely, a strong faith in God, and deserve commendation because they desire every Christian to hold to a strong, firm faith." ${ }^{36}$ However, he recognizes that "[w] hen a strong man travels with a weak man, he must restrain himself so as

\footnotetext{
32 Ngien, Fruit for the Soul, 2.

33 Kolb, Foreword, xiii.

34 Russell, preface to "Whether One May Flee," 475.

35 Though addressed to the pastor at Breslau, his explanation that "[b]ecause this letter will go out in print for people to read, I regard it useful to add some brief instructions on how one should care and provide for the soul in time of death" makes clear that Luther had a wider audience in view (see Luther, "Whether One May Flee," 485).

36 Luther, "Whether One May Flee," 476.
} 
not to walk at a speed proportionate to his strength." Those who remain during an outbreak must not bind the conscience of those who leave. Moreover, Luther chides those who infer that, since the plague is a judgment from God, it would be improper to flee and thus avoid his chastisement. ${ }^{37}$ Citing several biblical examples of individuals who fled from danger in order to save their lives, Luther charges that fleeing from an illness is no different than running from other dangers such as pestilence, war, or animals. He ridicules those who stay on the basis that believers should not run from a perceived judgment by arguing, by this logic:

When a house is on fire, no one should run outside or rush to help because such a fire is also a punishment from God. Anyone who falls into deep water dare not save himself by swimming but must surrender to the water as to a divine punishment ... Hunger and thirst are also great punishments and torture. Why do you eat and drink instead of letting yourself be punished until hunger and thirst stop by themselves? Ultimately such talk will lead to the point where we abbreviate the Lord's Prayer and no longer pray, "Deliver us from evil, Amen."38

Thus, while Luther commends those who have faith in God during the plague, he is sympathetic to those who flee to safety and mocks those who bind their consciences or behave like fatalists.

\subsection{Plague, Pastors, and Politics}

Second, Luther charges pastors and civil magistrates with a higher responsibility than the average citizen during upheaval. While he leaves it to the latter's conscience whether to flee, he charges that ministers must remain to provide spiritual care. The sole exception might be when several pastors in a region agree for some to leave and others to remain so that no believer is abandoned. ${ }^{39}$ Luther also holds civil authorities to a higher standard, stipulating on the basis

37 The Reformer's position on whether the plague is, in fact, a judgement from God or an attack of Satan can appear paradoxical. On the one hand, he does not argue with the one who believes it to be the latter in this scenario-and, in fact, he commends them for "willingly accept[ing] God's chastisement." On the other hand, he claims that one who flees from an outbreak might fairly say, "I am running away from evil and am doing what I can to protect myself against it. I am nevertheless in thy hands in this danger as in any other which might overtake me ... the devil never sleeps. He is a murderer from the beginning" (See Luther, "Whether One May Flee," 478).

38 Luther, "Whether One May Flee," 476.

39 Luther, "Whether One May Flee," 476. 
of Romans 13 that, "mayors, judges, and the like are under obligation to remain ... To abandon an entire community which one has been called to govern and to leave it without official or government ... is a great $\sin ^{\text {" }}{ }^{40}$ Yet, Luther was not merely concerned with restraining evil via civil means. Contrary to some Western Christians who express visceral aversion to collaboration with the authorities - or even obedience to their health guidelines - Luther endorses cooperation by believers wherever there is "an efficient government." Though adamant that when health facilities are sparse believers must care for one another "or risk the loss of salvation," ideally a responsible government would exist to aid the church with this burden. "That would indeed," he surmises, "be a fine, commendable, and Christian arrangement."41

\subsection{Love Your Neighbor}

Luther is adamant that love for neighbor must undergird whatever actions a Christian takes during a plague. Three times in his letter he cites the eschatological judgment of Matthew 25, where Christ separates his sheep from the goats, as a sober reminder that followers of Jesus dare not neglect the sick and needy. To do so, he charges, is to neglect Christ himself:

If it were Christ or his mother who were laid low by illness, everybody would be so solicitous and would gladly become a servant or helper. Everyone would want to be bold and fearless; nobody would flee but everyone would come running. And yet they don't hear what Christ himself says, "As you did to one of the least, you did it to me." ... If you wish to serve Christ and to wait on him, very well, you have your sick neighbor close at hand. ${ }^{42}$

This responsibility to care for one's neighbor may be the strongest emphasis in a letter full of rather firm directives. For Luther, even during a plague, no one may abandon a brother or sister, as doing so would be a failure "to assist and help him as he himself would like to be helped." ${ }^{43}$ He labels those who forsake the sick "murderers," as those who refuse to help a neighbor put out his housefire, ${ }^{44}$ and boldly asserts that "it is the devil who stirs up such abhorrence, fear, and

$\begin{array}{ll}40 & \text { Luther, "Whether One May Flee," } 476 . \\ 41 & \text { Luther, "Whether One May Flee," } 480 . \\ 42 & \text { Luther, "Whether One May Flee," } 482 . \\ 43 & \text { Luther, "Whether One May Flee," } 477 . \\ 44 & \text { Luther, "Whether One May Flee," } 479 .\end{array}$ 
loathing" of the diseased..$^{45}$ Love of neighbor extended to careful prevention of the plague's spread. Were Luther a twenty-first-century Christian, there is little reason to believe he would commend those who ignore pandemic guidelines. Those who "disdain the use of medicines" are not only "rash and reckless," but are guilty of sin against neighbor. Likewise are those who

do not avoid places and persons infected by the plague, but lightheartedly make sport of it and wish to prove how independent they are. They say that it is God's punishment; if he wants to protect them he can do so without medicines or our carefulness. This is not trusting God but tempting him. God has created medicines and provided us with intelligence to guard and take good care of the body so that we can live in good health ... [This person] is thus responsible before God for his neighbor's death and is a murderer many times over. ${ }^{46}$

Luther, rather, encourages his readers to take every precaution to avoid spreading disease. ${ }^{47}$ They should use whatever medicines are available and avoid going out in public when possible. Recall Luther's position on caring for those weaker in faith here as well. Should a supposedly "strong" individual behave irresponsibly and infect another who has taken proper precautions, they could not only cause physical harm but also demonstrate remarkable spiritual immaturity.

\section{$2.4 \quad$ Resist the Enemy}

Finally, ever the pastoral figure, Luther admonishes his fellow Christians to remain in prayer, reminding them that God would undoubtedly prevail over any satanic attack, whether in life or death. He stresses that believers must not grant the devil any glory by fearing what might come, and of Satan himself he inquires:

Or how could I, by flattering you, give you and your devils in hell reason to mock and laugh at me? No, you'll not have the last word! If Christ shed

45 Luther, "Whether One May Flee," 480.

46 Luther, "Whether One May Flee," 482.

47 On this front, Luther and the early Pentecostals demonstrate some commonality, the latter having canceled services during the Spanish flu epidemic. Alexander cites four different pentecostal newsletters between late 1918 and early 1919 that announce such closures in compliance with public health guidelines (see Alexander, Pentecostal Healing, 216). For Luther and these Pentecostals, avoiding public gatherings does not indicate a lack of faith in God; indeed, both consider, at points, whether the outbreaks are an act of his judgment. 
his blood for me and died for me, why should I not expose myself to some small dangers for his sake and disregard this feeble plague? If you can terrorize, Christ can strengthen me. If you can kill, Christ can give life. If you have poison in your fangs, Christ has far greater medicine ... Here is Christ and here am I, his servant in this work. Let Christ prevail!48

This is not to say that Luther encouraged his readers to "disregard this feeble plague" by behaving recklessly; recall that Luther reserved some of his harshest criticism for such people. What he warns against is unmitigated fear, lest the devil be glorified. Although Luther did not deny that the outbreak could be an expression of God's wrath, he acknowledged that Satan "enjoys himself at the terror and flight which he causes" during such crises. ${ }^{49}$ It is noteworthy that while Luther does not speculate at length as to the plague's cause, he consistently admonishes his readers to resist the work of the evil one as long as it remains an issue. Twenty-four times in his letter to Hess he mentions the devil, convinced the enemy may use not just the plague itself, but its effects, to sow destruction. Civil disorder, ${ }^{50}$ disdain for one's sick neighbor, ${ }^{51}$ and inadvertently spreading the plague through panic ${ }^{52}$ are several ways in which Luther envisions Satan using the occasion to serve his purposes. Therefore, believers are encouraged to remain vigilant; after all, "What do all kinds of pestilence or devils mean," he inquires, "over against God, who binds and obliges himself to be our attendant and physician?"53

48 Luther, "Whether One May Flee," 481.

49 Luther, "Whether One May Flee," 484.

$5^{\circ} \quad$ Luther, "Whether One May Flee," 477.

$51 \quad$ Luther, "Whether One May Flee," 480.

$5^{2}$ Luther, "Whether One May Flee," 483.

53 Luther, "Whether One May Flee," 481. Here, Luther's use of the term "physician" might resonate with many Pentecostals, historical and contemporary, who use the title in reference to Jesus (Alexander, Pentecostal Healing, 216). Note that Luther does not perceive this title for God, however, as being at odds with consulting human physicians for guidance, as charged by pentecostal pioneer Charles Parham, who flatly denied that a medical doctor could be a faithful Christian. See Douglas G. Jacobsen, Thinking in the Spirit: Theologies of the Early Pentecostal Movement (Bloomington: Indiana University Press, 2003), 22. The strength of Luther's position, then, is that it would allow Pentecostals to retain this cherished title for God while achieving a greater sense of balance. 
Though Veli-Matti Kärkkäinen sees in much of pentecostal spirituality "an ideal of victorious Christian living, an intensive faith expectation, and an emphasis on spiritual power to overcome problems in one's life," ${ }^{54}$ such an attitude may be something of a double-edged sword. While an expectation of divine healing is integral to the pentecostal experience, how are adherents to respond in times of widespread illness? This is where Luther is poised to offer a theologically robust yet pastorally considerate corrective, given his theology of the cross, the place of lament in his theology, and his navigation of the 1527 Black Death outbreak. Several implications, five of which will be outlined below, can be drawn from Luther's insights in order to help the contemporary church deal thoughtfully with its own outbreaks.

\subsection{Fear Not}

While contemporary readers might take Luther's exhortation not to fear as a guarantee that God will protect his people from sickness, a careful reading makes it clear that this alone is not what he had in mind. Luther did not have a resigned attitude toward sickness, nor did he deny God's ability to heal or, conversely, label evil good by downplaying pain. Heiko Oberman details that, for Luther, "Illnesses were so plainly a plague of the Devil that he put up desperate resistance to them. Patient acceptance of suffering as divinely ordained destiny was anything but pious unless there was nothing left to be done." 55 In his letter on the plague he repeatedly reminds his readers that Christ can overcome any illness. Yet, a more crucial point Luther conveys is that, for the Christian, even death itself is nothing to fear. Therefore, he labels an "out-and-out unbeliever" the one who abandons his sick neighbor. ${ }^{56}$ God himself is their physi-

54 Veli-Matti Kärkkäinen, "Theology of the Cross: A Stumbling-Block to PentecostalCharismatic Spirituality?," in Wonsuk Ma and Robert P. Menzies, eds., The Spirit and Spirituality: Essays in Honor of Russell P. Spittler (London \& New York: T\&T Clark International, 2004), 15 o.

55 Heiko Augustinus Oberman, Luther: Man between God and the Devil, trans. Eileen WalliserSchwarzbart (New Haven: Yale University Press, 2006), 330. This is another point where Pentecostals might find common ground with Luther; early adherents considered divine healing part of the gospel message and sickness something to be redeemed through the cross of Christ (Robinson, Divine Healing, 40). Though readers might sense a degree of tension between this attitude and Luther's assertion that God is revealed in suffering, perhaps this tension could help tamper the triumphalist attitudes of some Pentecostals while still remaining open to the possibility of healing.

$5^{6}$ Luther, "Whether One May Flee," 481. G.F. Taylor, who lived through the Spanish flu, appears to have taken a similar approach to the Reformer, explaining that although "it 
cian; ${ }^{57}$ when a believer serves the needy, he will sustain them, appealing to Psalm 41 as evidence. And, even in the face of death, Luther charges that it is the Christian's responsibility to sacrifice oneself for others, quoting 1John 3:16: "If Christ laid down his life for us, we ought to lay down our lives for the brethren"58 Finally, Luther contends that, should Satan induce fear in the believer, discouraging them from aiding the sick, they ought to respond to him as follows: "Just because you hate it, I'll spite you by going the more quickly to help my sick neighbor. I'll pay no attention to you." 59

\subsection{Consider One Another}

A Christian, even if they do not fear contracting an illness, should avoid places where they may spread one to others. The situation Luther addresses is somewhat different from what the twenty-first-century church faces; while Luther advises residents in one area of Germany during a localized outbreak, the COVID-19 pandemic of 2020, for example, forced the entire world into lockdown. However, Luther's core principle — that one should avoid unnecessarily venturing into public to avoid contributing to a plague's spread-remains relevant. Also helpful is his directive:

Now if a deadly epidemic strikes, we should stay where we are, make our preparations, and take courage in the fact that we are mutually bound together (as previously indicated) so that we cannot desert one another or flee from one another. First, we can be sure that God's punishment has come upon us, not only to chastise us for our sins but also to test our faith. ${ }^{60}$

might be possible to have faith to withstand the plague," nevertheless, "if the plague did come, it was no indication that one's faith had failed" (Alexander, Pentecostal Healing, 217). Luther goes even a step beyond Taylor; while the latter allows that believers might encounter sickness as a test of faith, the former also sees it as an occasion to actively love one's neighbor.

57 Interestingly, early pentecostal leader F.F. Bosworth identified this title as essential to God's identity, revealed in the cross, alongside "provider," "shepherd," and four other titles (Jacobsen, Thinking in the Spirit, 22). This motif of God as physician shows up so frequently in Luther and early pentecostal literature that it may warrant a study of its own.

$5^{8}$ Luther, "Whether One May Flee," 480. Luther goes on to argue that fear of being "in the presence of a sick person" is caused by the devil as well. Christians must resist such fear, lest they "sin thereby against God and man."

59 Luther, "Whether One May Flee," 48o.

6o Luther, "Whether One May Flee," 480. 
The principle that one must take every precaution not to infect others is linked to a theme that permeates Luther's letter-loving one's neighbor. Just as it is inexcusable to refuse to help the sick, it is inexcusable to be reckless and put others at risk of contracting an illness. ${ }^{61}$ Though encouraging Christians to be firm in the faith, he does not condone a "brash nor foolhardy" form of religion as a cover for irresponsibility. ${ }^{62}$ Luther summarizes his own approach by declaring:

I shall ask God mercifully to protect us. Then I shall fumigate, help purify the air, administer medicine, and take it. I shall avoid places and persons where my presence is not needed in order not to become contaminated and thus perchance infect and pollute others, and so cause their death as a result of my negligence. If God should wish to take me, he will surely find me and I have done what he has expected of me and so I am not responsible for either my own death or the death of others. If my neighbor needs me, however, I shall not avoid place or person but will go freely, as stated above. ${ }^{63}$

In short, Luther is a man of balance, sober and serious about taking proper precautions, but not paranoid nor stricken by fear so as to render him useless to those in need.

\subsection{Healing and Medicine}

Luther wisely refuses to drive a wedge between faith and the use of medicines. ${ }^{64}$ Those who do are, in Luther's eyes, like those who refuse to flee an outbreak on the assumption that it is a judgment of God. "No, my dear friends," Luther counsels, "that is no good. Use medicine; take potions which can help you; fumigate house, yard, and street; shun persons and places wherever your neighbor does not need your presence or has recovered, and act like a man who

$61 \quad$ See Luther, "Whether One May Flee," 484.

62 Luther, "Whether One May Flee," 483.

63 Luther, "Whether One May Flee," 483.

64 Although some Pentecostals have assumed that this conflict is inevitable, James K.A. Smith rightly argues that "the tension and apparent conflict is not between pentecostalism and science per se, but rather between pentecostalism and naturalism" (James K.A. Smith, "Is There Room for Surprise in the Natural World? Naturalism, the Supernatural, and Pentecostal Spirituality," in Smith and Yong, eds., Science and the Spirit, 37). This is vital, Smith explains, to avoid the misunderstanding that subscribing to the Hippocratic oath, as a physician, requires subscribing to a naturalistic worldview, a false equivalency that certain Pentecostals and secularists alike have assumed (34). 
wants to help put out the burning city."65 Tying into the principle of loving one's neighbor, Luther holds that those who have access to medicine to treat themselves and eliminate the possibility of spreading the disease must make use of it. "If one makes no use of intelligence or medicine," he cautions, "when he could do so without detriment to his neighbor, such a person injures his body and must beware lest he become a suicide in God's eyes." ${ }^{\prime 6}$ Resisting use, he concludes, is no more an act of faith than refusing to eat to avoid starvation. If God can heal the Christian, rendering medicine unnecessary, is he not likewise able to supernaturally prevent starvation? No, Christians are to use whatever means are available. ${ }^{67}$ The fact that God can and does protect and heal the believer on occasion is no excuse for them to neglect the natural means he supplies to ensure their well-being. For Pentecostalism, which emphasizes divine healing, Luther's approach is a balanced corrective, allowing the movement to retain a distinctive while granting a proper place to the role of medicine. The two need not be mutually exclusive but should be viewed as complementary.

\subsection{On Guard}

Linked to the principle of resisting fear, Luther's warnings against the attacks of the evil one are timeless. Convinced that "it is generally true of Christians that few are strong and many are weak,"68 Luther knew that, even if this plague had befallen them under God's providence, the devil would use it to sow division. He does not directly attribute the arrival of the plague to Satan himself; the closest example is when he submits his "opinion that all the epidemics, like any plague, are spread among the people by evil spirits who poison the air or exhale a pestilential breath which puts a deadly poison into the flesh." 69 Yet, even here, as he attributes the spread of the plague to powers of darkness, he argues that "this is God's decree and punishment to which we must patiently submit and serve our neighbor, risking our lives in this manner."70 Given that he seemed to believe the plague could be God's punishment, why grant any attention to Satan?

\footnotetext{
65 Luther, "Whether One May Flee," 483.

66 Luther, "Whether One May Flee," 483.

67 Here Pentecostals would do well to heed Luther to correct past imbalances; as Robinson documents, certain forefathers of their movement rejected medicine altogether, with William Seymour declaring it "for unbelievers" on the basis of James 5:14 (see Robinson, Divine Healing, 43).

68 Luther, "Whether One May Flee," 476.

69 Luther, "Whether One May Flee," 480.

70 Luther, "Whether One May Flee," 480.
} 
Luther was convinced that, even if Satan did not himself send the plague, he would not miss the opportunity to wreak havoc. There is a principle here for the contemporary church to consider, given the tension that has emerged in many congregations over their handling of the CoviD-19 outbreak. The devil is not to be found in a mask, a vaccine, or a public health restriction; nor is he especially at work in those who flee a deadly plague or remain. The work of the devil is primarily observed in the fear and division he induces within the body of Christ. It is perhaps, for this reason, that he ends his letter by entreating his readers for prayer against spiritual attack:

In closing, we admonish and plead with you in Christ's name to help us with your prayers to God so that we may do battle with word and precept against the real and spiritual pestilence of Satan in his wickedness with which he now poisons and defiles the world-particularly against those who blaspheme the sacrament, though there are other sectarians also. Satan is infuriated and perhaps he feels that the day of Christ is at hand..$^{71}$

Surely a committed Pentecostal, as much as anyone, would deeply appreciate such a spirit. Suspecting that the Lord's return may be imminent, ${ }^{72}$ he resolves to battle the real enemy—not his human beings, but the "spiritual pestilence of Satan." While Luther's context may be vastly different from the average twentyfirst-century believer's, his warning on this point is timeless.

\subsection{A Time to Weep}

Finally, Luther's theology allows for something that is all too often absent from contemporary Western Christianity: lament. In his volume God and the Pandemic: A Christian Reflection on the Coronavirus and Its Aftermath, N.T. Wright laments (no pun intended!) the modern church's seeming unwillingness during the current pandemic to simply acknowledge "that things are not as they should be."73 This may be due to a demand for a theodicy that immediately answers our questions; perhaps, conversely, we are not as comfortable with acknowledging our weakness as we ought to be. Luther, however, had no prob-

71 Luther, "Whether One May Flee," 486.

$7^{2}$ Luther's eschatological impulse might also serve as an area for further dialogue; during the Spanish flu, certain Pentecostals, such as A.J. Tomlinson, expressed this opinion as well (see Alexander, Pentecostal Healing, 216).

73 N.T. Wright, God and the Pandemic: A Christian Reflection on the Coronavirus and Its Aftermath (Grand Rapids, MI: Zondervan, 2020), 52. 
lem granting lament a place of prominence in his theology, owing to his foundational principle of God's revelation in the cross. "Lamentation," Ngien says, "belongs essentially to Luther's Theologica Crucis. It stands at the heart of Luther's theological hermeneutic, shaped as it is by a pastoral concern for the soul ... Lamentation is the language of suffering and thus a fitting category for a discourse with God." ${ }^{4}$ This, of course, makes sense in light of the Reformer's rebuke to theologians of glory who call "evil good and good evil." The fact is, pandemics are not good; no one should pretend they are. Pandemics cause immense suffering, economic loss, family tension, isolation, and, of course, death. This pain is only exacerbated in that the Christian really has no concrete explanation for why they come to pass. Yet, particularly in his writings on the Psalms, one discovers a robust theology of lament in Luther that is uncharacteristic of the modern Western church. ${ }^{75}$ Ngien further explains:

However, the reformer took no interest in abstract theodicy that asks, "If God, why evil?" for God is not on trial. Luther's theology of the cross cannot be converted into a speculative theodicy ... A theologian of the cross does not know why suffering strikes an innocent, but he does not have to question how God regards him, for God has disclosed decisively in the cross of Christ that he is for us, not against us.

Luther never questions God's existence, even when he cannot understand his providence. Rather, with the authors of Scripture, he pours out his heart to God while keeping his eyes on the cross. While believers may never fully understand suffering, they have a God who hears and cares. Thus, they may lament freely in the knowledge that, ultimately, death will not have the last word.

\subsection{Unresolved Issues}

Some questions remain unanswered; though encouraging individuals to avoid public places, Luther adamantly stipulates that "one must admonish the people to attend church and listen to the sermon so that they learn through God's word how to live and how to die."76 It is difficult to conclude how Luther might

\footnotetext{
74 Ngien, Fruit for the Soul, xxvii.

75 There are, of course, pentecostal exceptions to this, such as Narelle Jane Melton, "Lessons of Lament: Reflections on the Correspondence between the Lament Psalms and early Australian Pentecostal Prayer," Journal of Pentecostal Theology 20, no. 1 (2011): 68-80, https:// doi.org/10.1163/174552510X526232. However, a robust theology of lament has not historically been characteristic of Pentecostalism; thus, perhaps sustained engagement with Luther-including on the lament Psalm—-might help strengthen the tradition in this area.

Luther, "Whether One May Flee," 484.
} 
approach the modern situation, where most congregations have the ability to broadcast their services online when meeting is impossible. Given the reasoning behind his directive, that believers might hear Scripture preached, one might conclude that if Luther were a twenty-first-century believer he might not so firmly insist that the church gather in person. His resolution to "avoid places and persons where my presence is not needed" may extend to this scenario. Yet, this is little more than an educated guess, given that Luther's situation in 1527 so differed from the modern situation that this was simply not a consideration.

Moreover, one might question whether the plague was a result of God's chastisement or a test of faith, as Luther seems to argue. Regarding a full blown epidemic, Luther asserts, "we can be sure that God's punishment has come upon us, not only to chastise us for our sins but also to test our faith and love"despite citing no scriptural passages to prove we could be "sure" of such a thing. ${ }^{77}$ The fact that such a tension appears in his work over the providence of God and the work of the devil under such conditions further illustrates that there are no easy answers as to why such tragedies arise. ${ }^{78}$ Thus, it would be wise for believers to avoid making pronouncements as to whether a pandemic is indeed a result of God's judgment. Where Scripture does not speak in absolute terms, it might be best for Christians to avoid doing so.

Nevertheless, such details must not be allowed to overshadow Luther's wisdom. He was keenly aware of his own imperfections, having humbly requested that his readers "Pray for me, a poor sinner."79 It is unrealistic to expect one man to provide all the answers. That said, were the contemporary church to heed his advice in wholeheartedly loving their neighbor, adopting an appropriate theology of lament, and standing firm against the work of Satan, there could be little doubt the people of God would be better off for it.

Might Luther's approach to the plague of 1527 aid the pentecostal movement as it considers how to appropriately respond to plagues and pandemics in its own time? It seems that appropriating some of the Reformer's thought would be quite beneficial. Not only does Luther's theology of the cross help correct

77 Luther, "Whether One May Flee," 480. In fairness to the Reformer, his larger point here is one about God's testing of their love and faith. Nevertheless, such a broad, unqualified claim still seems rather unsubstantiated.

78 See, once again, note 28 for further details.

79 Luther, "Whether One May Flee," 487. 
a long-held imbalance in pentecostal theology, but his pastoral wisdom makes his contribution vital when one longs to hear a voice of reason amid the hysteria of modern society. There are few figures in Christian history whose theology and life experiences are better suited to address this deficiency in the pentecostal movement. Thus, as the world-and the church-finds itself in an unprecedented time, the occasion is ripe for a fruitful conversation between a timeless voice and this upstart, rapidly growing segment of the Christian faith. 